International Journal of Business and Management 4 (5): 01-10, 2020

e-ISSN: 2590-3721

(C) RMP Publications, 2020

DOI: $10.26666 / \mathrm{rmp} . \mathrm{ijbm} .2020 .5 .1$

\title{
Employment and labor policies. The case of Italy
}

\author{
Luca Rossi, Ing. PhD \\ Università degli Studi Niccolò Cusano - Telematica Roma, Via Don Carlo Gnocchi, 300166 Roma \\ e-mail: luca.rossi@unicusano.it
}

\begin{abstract}
This study analyses the impact of labor policies introduced in the last twenty years in Italy focusing on the direct influence on employment. Using different socio-economic variables and through the use of Principal Component Analysis and a generalized linear model (GLM), the analysis: i) highlights there is no empirical evidence to support that the Monti-Fornero and Jobs Act reforms have a statistically significant impact on the determination of employment levels in recent years.; ii) identifies the main variables that have a significant impact on the determination of employment in Italy. These findings confirm that the current situation is far from being considered desirable, not only for the reduction of workers' rights, but above all because this downsizing has not led to any substantial economic growth and hasn't helped to improve the structural conditions of the labor market. It would be desirable to understand what are the real determinants of sustainable economic growth, which are not to be found in the management of labor costs (especially in large companies), but instead lie in the dimensions of innovation, technological integration, the capacity of organizations companies to retain talent, human capital and skilled labor and to encourage work productivity through the flexibility of working conditions and the quality of life of employees.
\end{abstract}

Keyword: labour policies; employment; principal component analysis; Jobs act

\section{Introduction}

Labor policies, from the Treu package [1] to the dignity decree [2], are characterized by very different goals and policy orientations of law. The solutions adopted were conditioned by the political orientation of the legislators and by the economic and social urgencies of the period in which they were approved.

The purpose of this work is to estimate the effects of the measures, not by means of forecasting models but by verifying the effects highlighting whether these reforms have brought improvements in the world of work or whether other factors determine the employment rate of a country .

\section{Treu package}

The Treu package, by the actual name of Minister of Labor and Social Security during the Prodi government, was a set of laws enacted in 1997. The package had the main purpose of modernizing twentieth-century labor policy which was incapable of performing its protective functions in a market characterized, in those years, by the third industrial revolution and by the growing globalization [3-6]. The Legislator focused on incoming flexibility allowing temporary work, on the possibility of a part-time job and on a renewed attention towards the transition from school to work (apprenticeship and internships) [7-8].

The Treu package was the first measure on the labor market that hasn't only focused on the defense of the worker with respect to the company, but has actively sought to modify the employment contracts making hiring more flexible and simple. In Italy the labor market from 1997 until 2001 (end of the Prodi government) recorded an increase of 2 percentage points in the employment rate (from $43.3 \%$ to $45.3 \%$ ) and a decrease of 2.2 percentage points in unemployment ( from $11.2 \%$ to $9 \%$ ) (Source ISTAT "Occupati e disoccupati dati ricostruiti dal [9]").

Biagi reform

The Biagi reform (d.lgs. 10 September 2003, n.276), by the actual name of its promoter, continued the work of renewal of the labor market

Corresponding Author: Luca Rossi, Ing. PhD, Università degli Studi Niccolò Cusano - Telematica Roma, Via Don

Carlo Gnocchi, 300166 Roma, e-mail: luca.rossi@unicusano.it 
started with the Treu package, adapting to the Italian order some innovative solutions adopted in the others European countries, in order to increase employment and quality of work [10-11]. The innovative regulatory solutions included in this reform were:

- the inclusion of new types of contracts (co.co.pro, intermittent work contract, bipartite, project-based, occasional) to protect workers involved in activities that couldn't be regularized with the jurisprudential instruments present in labor law in the 1990s;

- more space given to employment agencies;

- the creation of the institute for the certification of employment contracts.

The concreteness of this intervention profoundly changed some traditional points of Italian labor law and during those years the unemployment rate dropped to $6.1 \%$ calculated in 2007 (before the Italian economic crisis) and both youth and female employment grew (categories suffering in the Italian labor market) (Source ISTAT "Occupati e disoccupati dati ricostruiti dal [9]").

\section{Fornero reform}

After an initial work dedicated to public accounts and pensions, the Monti Government gave much attention to the problem of work. In June 2012, passed the law no. 92, known as Fornero reform, whose objective was to combat the precariousness of the work that had taken place with the Biagi reform and the Treu package [12]. In order to achieve the objective, the recruitment costs for all contracts were increased, with the exception of the permanent contract. The apprenticeship contract was affected by the restrictive measure of the hiring obligation of half of the apprentices involved in the enterprise. In favor of companies there was the modification of Article 18 of the Italian Constitution: in the case of economic dismissal the worker must not necessarily be inserted but can be compensated with an economic indemnity.

This project also included the reorganization of social safety nets (creation of ASpI and miniASpI), the establishment of bilateral solidarity funds, new guidelines on internships, measures on reconciling work and life, and tightening on resignation in white.
This reform, untimely compared to the economic moment that Italy was experiencing, didn't lead to growth: unemployment grew by two points in two years, the employment rate fell by more than one point. Youth unemployment rose from $35.3 \%$ in 2012 to $42.7 \%$ in 2014 (Source ISTAT "Occupati e disoccupati dati ricostruiti dal [9]"). The problem of youth inactivity, photographed from the statistics on NEETs (Not in Education, Employment or Training), became a common topic of discussion. [13-14].

The Jobs Act

The first decision of the Renzi Government technicians, designated to intervene on the employment problem, was to eliminate the limits imposed by the 2012 reform on the labor market [15-18]. The first intervention of the executive was the liberalization of fixed-term contracts (d.1. 20 March 2014, n. 34) followed therefore by the main reform presented by the Renzi Government: the Jobs Act. In this aggregate of laws and decrees the legislator dealt with:

- the reorganization of social safety nets after the loss of the job (NASpI) [19];

- the regulation of the new permanent contract with increasing safeguards;

- the reorganization of the contractual types (repeal of the project contract);

- the reform of social safety nets, inspection services and active labor policies (with the creation of the Anpal) [20].

An extremely broad and structured reform that, however, had positive results in terms of greater employment thanks to a provision contained in the Stability Law of 2015: in that year the companies had a reduction in the amount of social security contributions of a worker who had signed a permanent contract in that year.

This incentive cost the state coffers EUR 18 billion.

However, with the measures approved between 2014 and the first months of 2018, a decrease in the unemployment rate of 1.5 percentage points, an increase in the employment rate of 1.4 points and a decrease of 1.5 points in the general inactivity rate (Source ISTAT "Occupati e disoccupati dati ricostruiti dal [9]").

\section{Data and methodology}

The aim of the work is to highlight the relationships existing between employment in Italy (quantitative discrete macroeconomic variable), 
labor policies and other variables which according to Keynesian economic theory [21] and the results of Phillips econometric studies [22] are correlated or decisive for the growth of a country's employment.

The data have been collected using the databases of the European Central Bank (ECB) and elaborated by composing a coherent dataset on the temporal level from the first quarter of 2003 through the second quarter of 2018 , for a total of 15 years of observations on a quarterly basis. The sample size of the dataset for time series is $\mathrm{N}=62$.

\section{Data}

Labor policies have been transformed into a categorical variable at three levels corresponding to the periods of validity of the Worker's Statute before the Monti-Fornero law, during the MontiFornero reform and then with the Jobs act reform.

The dataset created consists of 30 variables: a categorical variable for labor policies and 29 statistical variables collected on the basis of the Keynesian theory and the trade-off between inflation and unemployment that is proposed by Phillips. The variables have been chosen considering that

1. The conditions of access to credit at the aggregate level influence the operations, the competitiveness, the investment decisions and the internal financial balance of the companies, with the consequence that the credit markets and their developments have some effect on the aggregate employment levels;

2. The costs that companies claim have a direct effect on their ability to hire new employees. This requires an analysis of costs at the aggregate level not only of the workforce, but also of the buildings and financial investments in progress of the company;

3. Exports from Italy have significant economic impacts on the volume of business of companies and contribute to determining the demand for internal labor. This requires the inclusion in the data set of statistical variables that consider exports in the determining sectors of the Italian economy;

4. Demographic quantities, such as the number of residents in the country, the number of families and the average number of family members have a direct effect on the level of employment.

The statistical variables considered and included in the dataset are summarized in Table 1.

Table 1: Statistical variables included in the dataset

\begin{tabular}{|c|c|}
\hline Statistical variables & \multicolumn{1}{c|}{ Variable type } \\
\hline Employment & discrete dependent variable \\
\hline family credit & continue variable \\
\hline market credit companies & continue variable \\
\hline creditworthy families & continue variable \\
\hline large companies credit & continue variable \\
\hline long-term business credit & continue variable \\
\hline short-term business credit & continue variable \\
\hline PMI credit & continue variable \\
\hline Index of real estate prices (companies) & continue variable \\
\hline 10years BOT yeald & continue variable \\
\hline labour cost - other items & continue variable \\
\hline labour cost - building sector pay & continue variable \\
\hline labour cost - business pay & continue variable \\
\hline export capital goods & continue variable \\
\hline export of chemical & continue variable \\
\hline
\end{tabular}




\begin{tabular}{|c|c|}
\hline export food consumer goods & continue variable \\
\hline export non-food consumer goods & continue variable \\
\hline exports of energy & continue variable \\
\hline export alcohol and tobacco & continue variable \\
\hline export intermediate goods & continue variable \\
\hline export machinery and equipment & continue variable \\
\hline export manufacturing & continue variable \\
\hline export other products & continue variable \\
\hline export oil & continue variable \\
\hline export raw materials & continue variable \\
\hline total export & continue variable \\
\hline number of residents & discrete variable \\
\hline number of families & discrete variable \\
\hline persons a family & discrete variable \\
\hline Italian laws & categorical variable \\
\hline
\end{tabular}

A graphical representation of the historical series of employment from 2003 to 2018 is shown in Figure 1.

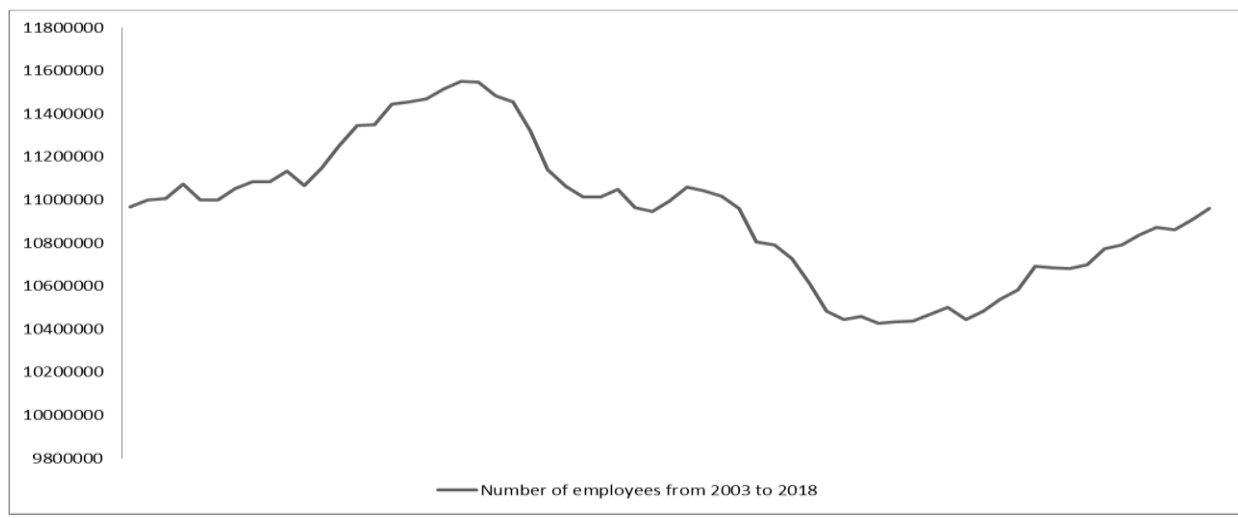

Figure 1: Number of employees in Italy from 2003 to 2018.

To investigate the distributive properties of the employment variable an empirical density estimate was performed using a non-parametric Gaussian kernel (fig. 2) [23]. The graph shows the
Gaussian protuberances on the sides of the central distribution indicating the presence of different political periods in the historical series. 


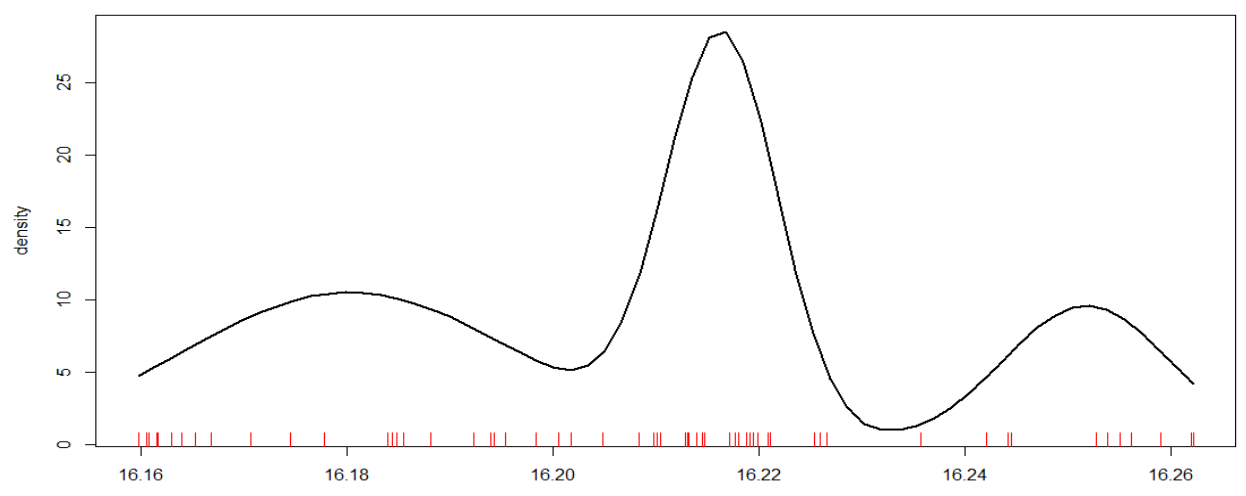

Figure 2: Kernel of density.

\section{Methodology: a multivariate approach}

The search for a model suitable to study the dependence structure between a dependent variable and a set of explicative variables is well known in literature as a classical regression problem.

Unfortunately, the situation treated in this paper includes more than one problem. First of all the mixed nature of the variables (discrete and continue) does not allow for the use of simple regression methods. In addition many variables used are considered as independent in a regression model but they could present a high degree of correlation, due to the fact that they might measure the same characteristics [24].

In order to overcome the above-mentioned problems, the following strategy has been adopted: a principal component analysis among the employment and the predictors (29 variables previously defined except for the variable "Italian laws"). Principal component analysis (PCA) [25] is a multivariate technique that analyzes a data table in which observations are described by several inter-correlated quantitative dependent variables. In particular this procedure uses an orthogonal transformation to convert a set of observations of possibly correlated variables into a set of values of linearly uncorrelated variables called principal components (PC). Each $\mathrm{PC}$ is a linear combination of the original variables. The PCs form the basis of the respective vector space and they are arranged in order of decreasing variance. Thus the first PC carries the most information regarding the original data, and so on. The results of PCA using R are listed in Table 2.

Table 2: Factor Loading Matrix for Principal Component Analysis

\begin{tabular}{|c|c|c|c|c|c|c|c|c|c|c|}
\hline & PC1 & PC2 & PC3 & PC4 & PC5 & PC6 & PC7 & PC8 & PC9 & PC10 \\
\hline $\begin{array}{l}\text { Standard } \\
\text { deviation }\end{array}$ & 3.022 & 1.630 & 1.580 & 1.425 & 1.393 & 1.112 & 1.037 & 0.998 & 0.945 & 0.927 \\
\hline $\begin{array}{l}\text { Proportion } \\
\text { of variance }\end{array}$ & 0.315 & 0.092 & 0.086 & 0.070 & 0.067 & 0.043 & 0.037 & 0.034 & 0.031 & 0.030 \\
\hline \multirow[t]{2}{*}{$\begin{array}{l}\text { Cumulative } \\
\text { proportion }\end{array}$} & 0.315 & 0.407 & 0.493 & 0.563 & 0.63 & 0.67 & 0.71 & 0.744 & 0.775 & 0.805 \\
\hline & PC11 & PC12 & PC13 & PC14 & PC15 & PC16 & PC17 & PC18 & PC19 & PC20 \\
\hline $\begin{array}{l}\text { Standard } \\
\text { deviation }\end{array}$ & 0.894 & 0.878 & 0.824 & 0.722 & 0.684 & 0.615 & 0.601 & 0.558 & 0.516 & 0.495 \\
\hline $\begin{array}{l}\text { Proportion } \\
\text { of variance }\end{array}$ & 0.027 & 0.027 & 0.023 & 0.018 & 0.016 & 0.013 & 0.012 & 0.011 & 0.009 & 0.008 \\
\hline \multirow[t]{2}{*}{$\begin{array}{l}\text { Cumulative } \\
\text { proportion }\end{array}$} & 0.832 & 0.859 & 0.882 & 0.900 & 0.916 & 0.929 & 0.941 & 0.952 & 0.962 & 0.970 \\
\hline & PC21 & PC22 & PC23 & PC24 & PC25 & PC26 & PC27 & PC28 & PC29 & \\
\hline $\begin{array}{l}\text { Standard } \\
\text { deviation }\end{array}$ & 0.465 & 0.421 & 0.359 & 0.326 & 0.309 & 0.275 & 0.209 & 0.141 & 0.014 & \\
\hline $\begin{array}{l}\begin{array}{l}\text { Proportion } \\
\text { of variance }\end{array} \\
\end{array}$ & 0.007 & 0.006 & 0.004 & 0.004 & 0.003 & 0.003 & 0.001 & 0.001 & 0.000 & \\
\hline $\begin{array}{l}\text { Cumulative } \\
\text { proportion }\end{array}$ & 0.978 & 0.984 & 0.988 & 0.992 & 0.995 & 0.998 & 0.999 & 0.999 & 1.000 & \\
\hline
\end{tabular}


The first 9 principal component variance summed up a contribution rate of $77.5 \%$, among which the first principal component variance had a contribution of $31.5 \%$. In this way a large set of variables has been transformed into a smaller one that still contains most of the information in the large set.

It is further interesting, for the purposes of this study, to understand the specific composition of each constructed factor. This information is necessary to understand the weight that each statistical variable has on the determination of the single PC. Table 3 shows the composition of the first PC highlighting for each the first 6 statistical variables with a greater positive influence and the first 6 with a greater negative influence for the determination of the single PC.

Table 3: PC1 composition

\begin{tabular}{|lc|lc|}
\hline Variable & $\begin{array}{c}\text { Regression } \\
\text { coefficient }\end{array}$ & Variable & $\begin{array}{c}\text { Regression } \\
\text { coefficient }\end{array}$ \\
\hline export manufacturing & 0,1332 & persons a family & -0.2044 \\
\hline $\begin{array}{l}\text { export food consumer } \\
\text { goods }\end{array}$ & 0.1361 & large companies credit & -0.1747 \\
\hline export raw materials & 0.1416 & short-term business credit & -0.1619 \\
\hline export of chemical & 0.1455 & long-term business credit & -0.1399 \\
\hline Number of residents & 0.1982 & PMI credit & -0.1310 \\
\hline Number of families & 0.2108 & creditworthy families & -0.1197 \\
\hline
\end{tabular}

The interpretation of the above data is rather intuitive, for example, the modalities "number of residents" $(0.20)$ and "number of families" $(0.21)$ have the highest positive influence on the first principal component. In addition variable "persons a family" $(-0.20)$ has a negative impact on the first principal component. In this way it is possible to quantify the role of each statistical variable of the dataset in the determination of the single PC.

Finally to estimate the relationships existing between employment in Italy and the other independent variables, in particular "labor policies" has been used a factor model: a multiple regression model to explain employment dynamics in Italy.

\section{Factor model: analysis of data}

The factor model is the final phase of the present work and allows us to understand if the job reforms have actually played a role in determining the employment levels observed in the last 15 years.

For the model estimation, the first 9 PCs have been considered, which summed up explain more than $75 \%$ of the total variability of the dataset and have been computed by excluding the categorical variable that represents labor policies over the past 15 years. This last variable has been included separately in the model specification.

The factor model used is a generalized linear model (GLM) [26-27] :

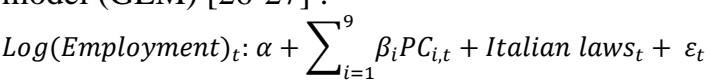
where, $\varepsilon_{t} \sim \mathrm{N}\left(0, \sigma^{2}\right)$.

In this model the multicollinearity doesn't occurs because the 9 principal components variables used are uncorrelated by construction. The regression model values obtained with the glm function of $\mathrm{R}$ are shown in table 4.

Table 4: Regression model values

\begin{tabular}{|ccccc|}
\hline & Estimate & $\begin{array}{c}\text { Std. } \\
\text { Error }\end{array}$ & t value & $\operatorname{Pr}(>|\mathbf{t}|)$ \\
\hline (Intercept) & 16.209454 & 0.004116 & 3938.183 & $<2 \mathrm{e}-16$ \\
\hline $\begin{array}{c}\text { Italian } \\
\text { laws }\end{array}$ & $\mathbf{- 0 . 0 0 2 7 3 0}$ & $\mathbf{0 . 0 0 5 7 0 4}$ & $\mathbf{- 0 . 4 7 9}$ & $\mathbf{0 . 6 3 4 2 9 7}$ \\
\hline PC1 & -0.004821 & 0.001246 & -3.868 & 0.000312 \\
\hline
\end{tabular}




\begin{tabular}{|lcccc|}
\hline PC2 & 0.007774 & 0.001341 & 5.799 & $4.23 \mathrm{e}-07$ \\
\hline PC3 & -0.006819 & 0.002032 & -3.356 & 0.001499 \\
\hline PC4 & 0.001804 & 0.001428 & 1.263 & 0.212288 \\
\hline PC5 & -0.002036 & 0.001508 & -1.350 & 0.182906 \\
\hline PC6 & 0.001746 & 0.001826 & 0.956 & 0.343733 \\
\hline PC7 & -0.001173 & 0.001963 & -0.598 & 0.552655 \\
\hline PC8 & 0.006450 & 0.002079 & 3.102 & 0.003132 \\
\hline PC9 & 0.006022 & 0.002172 & 2.772 & 0.007752 \\
\hline
\end{tabular}

The least significant variable, the one that has the highest p-value, is precisely the categorical variable related to labor policies. This implies that there is no empirical evidence to support that the Monti-Fornero and Jobs Act reforms have had a statistically significant impact on the determination of employment levels in recent years. This circumstance is rather curious, considering that the intention declared by the legislators was to increase employment levels thanks to greater flexibility and mobility in the labor market.

To obtain a model that highlights the statistical variables that really affect employment in Italy, a forward elimination selection procedure was used. This procedure gradually excludes from the choice of variables the one that at each fitting iteration has the highest p-value. At the end of the procedure, the model with the Akaike coefficient [28] minor is shown in table 5.

Table 5: Regression model values

\begin{tabular}{|ccccc|}
\hline & Estimate & Std. Error & t value & $\operatorname{Pr}(>|\mathbf{t}|)$ \\
\hline (Intercept) & 16.207737 & 0.002023 & 8010.112 & $<2 \mathrm{e}-16$ \\
\hline PC1 & -0.005322 & 0.000675 & -7.885 & $1.19 \mathrm{e}-10$ \\
\hline PC2 & 0.008009 & 0.001251 & 6.402 & $3.35 \mathrm{e}-08$ \\
\hline PC3 & -0.007572 & 0.001291 & -5.865 & $2.51 \mathrm{e}-07$ \\
\hline PC8 & 0.006253 & 0.002045 & 3.058 & 0.00341 \\
\hline PC9 & 0.006164 & 0.002158 & 2.856 & 0.00601 \\
\hline
\end{tabular}

In this model all the coefficients are

sufficiently centered on 0 . In fig. 3 have been plotted the residuals vs fitted values. statistically significant and the residues are

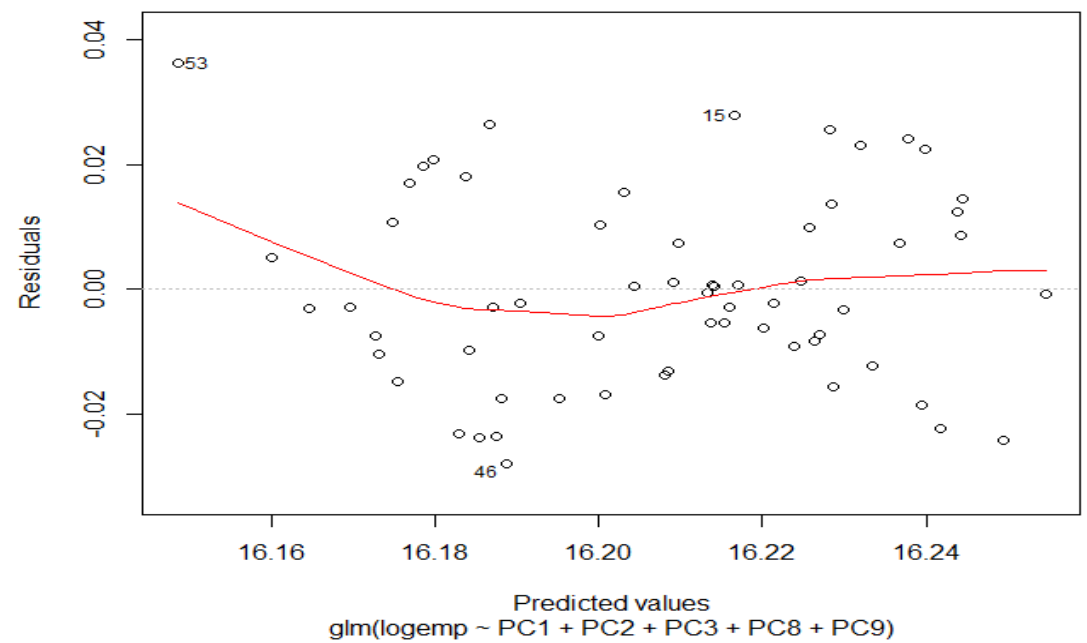

Figure 3: The residuals vs fitted values 
The plot indicates that the residuals and the fitted values are uncorrelated, as they should be in a homoscedastic linear model with normally distributed errors [29].

A further diagnostic criterion for the goodness of the estimated model is that of the QQ plot [30], a graph that highlights the normality of the residues by studying their distribution. The results of the QQ plot on the residues are highlighted in Fig. 4.

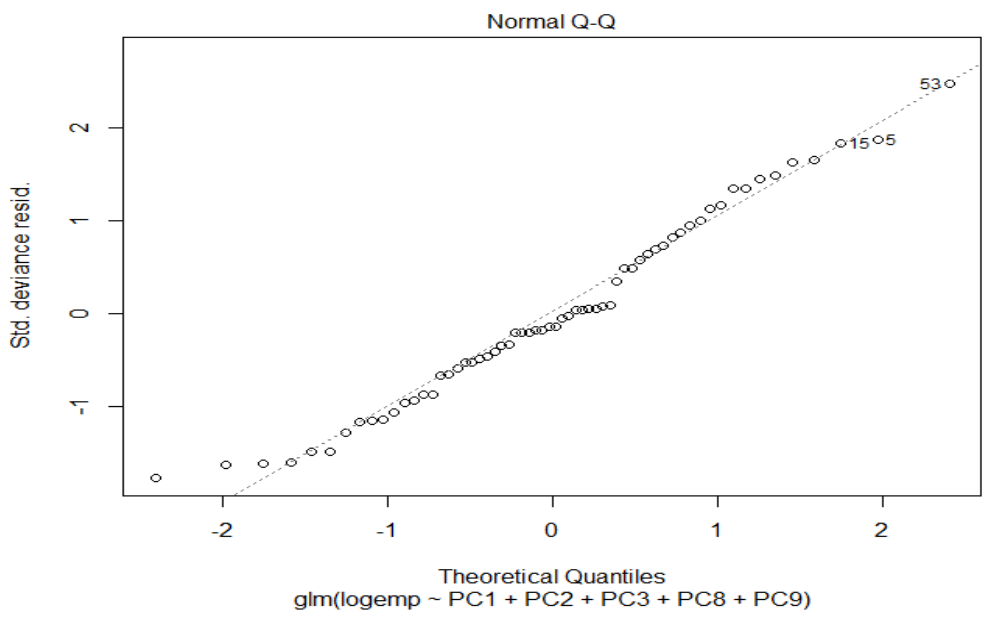

Figure 4: QQ-plot

Also the results of the QQ-plot seem rather encouraging, in fact, except for the first two points on the lower left, each point seems to be located quite precisely on the line (this indicates that the residues are normally distributed).

\section{Results}

Considering the analysis conducted and illustrated, it is possible to draw conclusions on the statistical variables that really have an important weight in determining employment levels. In particular, considering the significant $\mathrm{PCs}$ at a confidence level equal to or less than 1\% (PCs $1,2,3,8$ and 9) and in combination with the analysis conducted on the statistical variables that make up the single PCs, we obtain that the variables contained in the dataset, which have a significant impact on the determination of employment are: Number of families; Number of residents; Exports (predominant positive correlation); Market credit companies (predominant negative correlation); Labour cost (predominant negative correlation).
The results obtained indicate that:

- demographic balances influence the labor market in a decisive way, as they quantitatively determine the available labor force;

- exports (which derive from the foreign demand for goods produced in Italy) have a positive weight in companies' demand for labor.

- the possible relationship between credit and employment is more ambiguous, at least in principle, as whilst it may be true that greater access to credit would lead to a greater immediate availability of financial resources, it is also true that for companies a greater bank exposure determines a greater quantity costs to be borne by companies, with a consequent reduction in the resources allocated for the recruitment of new employees;

- The cost of labor, being a business expense, plays a negative role in determining the assumptions.

The analysis carried out attributes no importance to the legislative provisions in determining employment levels in recent years, 
suggesting that the reforms have been substantially ineffective and that the reasons of the various legislators have been disregarded (a circumstance that has been the subject of jurisprudential debate and economic activity in the last few years and which is not at all unprecedented).

\section{Conclusions}

In this work, several aspects related to the discipline of labor policies were considered after the promulgation of important reforms such as Monti-Fornero and the jobs act.

Starting from the Monti-Fornero reform it has been possible to appreciate a precise intention on the part of the legislator to facilitate the dynamics of company organization, making it easier for the company to dismiss and to reduce the obligations to re-employ the dismissed person. With the jobs act, instead, we see the most complete obscuration of worker protection in the context of dismissal. This is a couple of reforms that have played openly against the interests of workers especially at a time of particular difficulty in terms of national unemployment and youth unemployment. It seems somewhat ironic that, in times of crisis and recession, a dramatic increase of unemployment values is accompanied by an equally significant reduction of workers' rights. Teaching is at the same time of historical and economic matrix: economic growth determines a strengthening of the negotiating power of the working class, due to the greater demand for labor and skilled labor, vice versa, periods of recession entail economic and financial difficulties for companies and a decrease in labor demand. With these reforms, we are witnessing a total fragmentation of the protection of the worker who has been protected for half a century with labor policies and interactions between the union forces, governments and businesses. The economic reasons of large companies have been reinforced with the jobs act especially in the context of the discipline of dismissals evident in the contract of indefinite duration with increasing protections. Furthermore, after more than two years from the issuing of the decree, the employment conditions of Italian workers do not appear to have improved significantly in terms of decreasing the unemployment rate. During these years, almost nothing has been done to counter the enormous phenomenon of undeclared work, and to protect young workers, fortunate in finding regular employment with permanent contracts, who enter the labor market on systematically worse terms than older workers.

The current situation is far from being considered desirable, not only for the reduction of workers' rights, but above all because this downsizing has not led to any substantial economic growth and hasn't helped to improve the structural conditions of the labor market. It would be desirable to understand what are the real determinants of sustainable economic growth, which are not to be found in the management of labor costs (especially in large companies), but instead lie in the dimensions of innovation, technological integration, the capacity of organizations companies to retain talent, human capital and skilled labor and to encourage work productivity through the flexibility of working conditions and the quality of life of employees.

\section{References}

[1] Law decree 24/06/1997, n. 196

[2] P. Faraguna, C. Fasone and G. Piccirilli (2018) The italian journal of public law volume 10, issue 2.

[3] G. Pera (1969). I Licenziamenti Nell'interesse Dell'impresa. Atti Delle Giornate Di Studio Di Firenze, 27-28 Aprile 1968, Giuffrè, Milano.

[5] F. Liso (1982). La Mobilità Del Lavoratore In Azienda: Il Quadro Legale. Franco Angeli, Milano. 1

[6] M. Biagi(1997). Mercati e rapporti di lavoro: commentario alla Legge 24 giugno 1997, $n$. 196. Giuffrè.

[7] Maresca (2012). Il Nuovo Regime Sanzionatorio Del Licenziamento Illegittimo: Le Modifiche Dell'art. 18 Statuto Del Lavoratori. Rivista Italiana di Diritto del Lavoro.

[8] G. Amoroso (2015). Le Tutele Sostanziali E Processuali Del Novellato Art. 18 Dello Statuto Dei Lavoratori Tra Giurisprudenza Di Legittimità E Jobs Act. Rivista Italiana di Diritto del Lavoro.

[9] https://www.istat.it/it/files//2013/04/Notametodologica.pdf

[10] M. Tiraboschi (2004), La riforma Biagi del mercato del lavoro. Giuffrè.

[11] Nogler (2007). La Disciplina Dei Licenziamenti Individuali Nell'epoca Del Bilanciamento Tra "Principi" Costituzionali. 
Giornale di Diritto del lavoro e delle relazioni industriali.

[12] M. Magnani, M. Tiraboschi (2012). La nuova riforma del lavoro. Commentario alla legge 28 giugno 2012, $n .92$ recante disposizioni in materia di riforma del mercato del lavoro in una prospettiva di crescita. Giuffrè.

[13] E. Massagli, G. Zilio Grandi (2013). Dal decreto legge $n$. 76/2013 alla legge $n$. 99/2013 e circolari "correttive": un percorso di lettura. Adapt University Press, Modena.

[14] G. Rosolen, F. Seghezzi (2016). Garanzia Giovani due anni dopo. Analisi e proposte. Adapt University Press, Modena.

[15] M.P. Potestio 82015). Il Jobs Act E Il Modello Di Blanchard E Tirole. Il Mulino, Bologna.

[16] A. Vallebona (2015). Breviario di diritto del lavoro. Giappichelli editore.

[17] M. De Luca (2015). Tre Parole Del Legislatore Non Bastano Per La Rivoluzione Copernicana Promessa: Il Jobs Act Alla Prova Della Giurisprudenza. Lavoro nella Giuriprudenza.

[18] M. Tiraboschi (2016). Il Piano nazionale Industria 4.0: una lettura lavoristica. Labour and law issues, vol. 2, no. 2.

[19] R. Pessi, C. Pisani, G. Proia, A. Vallebona (2015). Jobs Act E Licenziamento. Torino: Giappichelli.

[20] P. Ichino (2016), La Riforma Del Mercato Del Lavoro Tra Diritto Ed Economia. Report at La Scuola Della Magistratura.

[21] R. Studart (1995). Investment Finance in Economic Development. Taylor \& Francis Group London

[22] P.C.B. Phillips (2001). The Bill Phillips Legacy of Continuous Time Modelling and
Econometric Model Design. Cowles Foundation

[23] Dejin Yu, Michael Small, Robert G. Harrison, and Cees Diks Phys. Efficient implementation of the Gaussian kernel algorithm in estimating invariants and noise level from noisy time series data. American Physical Society.

[24] S. Maitra \& J. Yan (2008). Principle Component Analysis and Partial Least Squares: Two Dimension Reduction Techniques for Regression. Seattle, WA: Casualty Actuarial Society.

[25] S. Wold, K. Esbensen and P. Geladi (1987). Principal component analysis. Chemometrics and Intelligent Laboratory Systems Volume 2, Issues 1-3, Pages 37-52.

[26] P. McCullagh, A. Nelder (1989). Generalized Linear Models. Monographs on Statistics and Applied Probability.

[27] Madsen, Henrik; Thyregod, Poul (2011). Introduction to General and Generalized Linear Models. Chapman \& Hall/CRC.

[28] Akaike, H. (1974). A new look at the statistical model identification. IEEE Transactions on Automatic Control, 19 (6), 716-723

[29] F. J. Anscombe \& John W. Tukey (1963). The Examination and Analysis of Residuals. Technometrics, 5:2, 141-160.

[30] Myerson, J., Adams, D.R., Hale, S. et al.(2003). Analysis of group differences in processing speed: Brinley plots, Q-Q plots, and other conspiracies. Psychonomic Bulletin \& Review. 